\title{
Development of a Dielectric Ceramic Based on Diatomite-Titania Part One: Powder Preparation and Sintering Study
}

\section{(Desenvolvimento da Cerâmica Dielétrica Baseada em Diatomita-Titania Parte 1: Preparação do Pó e Estudo de Sinterização)}

\author{
Elcio Correia de Souza Tavares, \\ Jamilson Pinto Medeiros, \\ Uílame Umbelino Gomes and \\ Wilson Acchar
}

\author{
Universidade Federal Rio Grande do Norte \\ Departamento de Física Teórica e Experimental \\ C.P. 1641, Lagoa Nova, Natal, RN \\ 59072- 970, Brazil
}

Resumo

Este trabalho apresenta um estudo da preparação dos pós e da sinterização de misturas de diatomita-titânia . Foram realizadas medidas de difração de raios X, ATD, ATG, assim como análises químicas e microestrutural. O processo de sinterização foi investigado em função do tempo e da temperatura de sinterização, da variação de massa, da contração linear e da energia de ativação. Os resultados mostram que a sinterização da diatomita-titânia pode ser descrita pelo mecanismo do fluxo viscoso.

\section{INTRODUCTION}

The development of new materials (among them advanced ceramics) with properties better to the already existent is one of the greatest aim of the present scientific research.

Advanced ceramics have been employed in the fabrication of ferroelectrics, semiconductors, dielectrics, etc [1]. In this work is presented a study of a mixture of diatomite and titania aiming to obtain a new dielectric ceramic with possible technological use.

\section{EXPERIMENTAL PROCEDURE}

The starting materials were diatomite acquired in the nature state by the Diafil of Natal-RN (Brazil) and titania (titanium dioxide $\mathrm{TiO}_{2}$ ) obtained in the nature as anatase, transferred by the FaenquilCemar of Lorena-SP.

Samples were prepared by sintering uniaxial pressed mixtures (200 MPa) of titania with 0,25 (D25), 50 (D50), 75 (D75) and 100

\begin{abstract}
This work presents powder preparation and sintering experiments of a mixture diatomite-titania. X-ray diffraction, DTA, TGA as well as chemical and microstructural analyses were made. The sintering process was investigated as a function of sintering temperature and time, mass variation, linear shrinkage and activation energy. The results show that sintering of diatomite-titania could be described by a viscous flow mechanism.
\end{abstract}

(D100) wt \% of diatomite. The powder was prepared by calcination $\left(900^{\circ} \mathrm{C}\right)$, milling and sieving (400 mesh). The material was sintered in air at temperatures between $1200{ }^{\circ} \mathrm{C}$ and $1500{ }^{\circ} \mathrm{C}$ for 0.5 to $48 \mathrm{~h}$.

The sintering constant $(\mathrm{k})$ and the activation energy $(\mathrm{Q})$ were calculated respectively by [1]:

$$
\begin{aligned}
& \mathrm{K}=\ln \left[\left(\Delta \mathrm{L} / \mathrm{L}_{\mathrm{o}}\right)_{1} /\left(\Delta \mathrm{L} / \mathrm{L}_{\mathrm{o}}\right)_{2}\right] / \ln \left(t_{1} / t_{2}\right) \\
& \ln \frac{t_{1}}{t_{2}}=\frac{Q}{R}\left[\frac{1}{T_{1}}-\frac{1}{T_{2}}\right]
\end{aligned}
$$

where $\mathrm{T}$ and $\mathrm{t}$ are respectively the sintering temperature and time; the indexes 1 and 2 refer to different conditions, $\mathrm{R}$ is the gas constant and $\left(\Delta \mathrm{L} / \mathrm{L}_{\mathrm{o}}\right)_{1}$ and $\left(\Delta \mathrm{L} / \mathrm{L}_{\mathrm{o}}\right)_{2}$ are the linear shrinkage of two different samples.

$\mathrm{X}$-ray diffraction analyses were made with $\mathrm{CuK}_{\alpha}$ radiation for phase identification.

The microstructures of specimens were analyzed by scanning 
electron microscopy (SEM).

The mass variation and the linear shrinkage were measured using the usual expressions.

\section{RESULTS AND DISCUSSION}

Table I shows the chemical analysis of diatomite (D), calcined diatomite $(\mathrm{CD})$ and titania $(\mathrm{T})$. It can be seen that the calcined diatomite is composed basically of $\mathrm{SiO}_{2}$ and $\mathrm{Al}_{2} \mathrm{O}_{3}$, with small quantities of others oxides, while titania has purity larger than 99.99\%. Table II presents some characteristics of the used materials, with the calcined titania indicated as CT. The powders have their densities in agreement with the literature [2,3] and we can note that the specific, surface area rises proportionally to the amount of

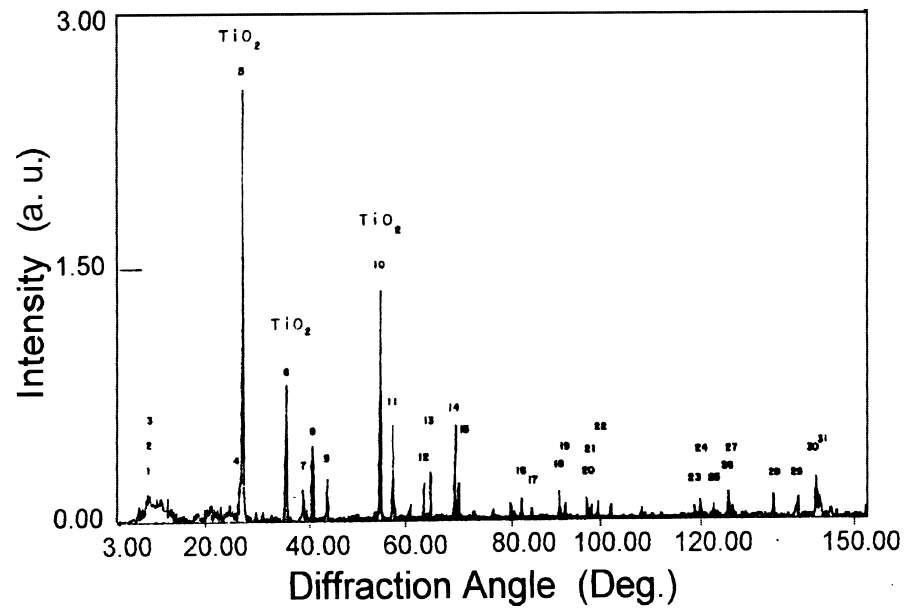

Figure 1: $X$-ray diffractogram of pure $\mathrm{TiO}_{2}$.

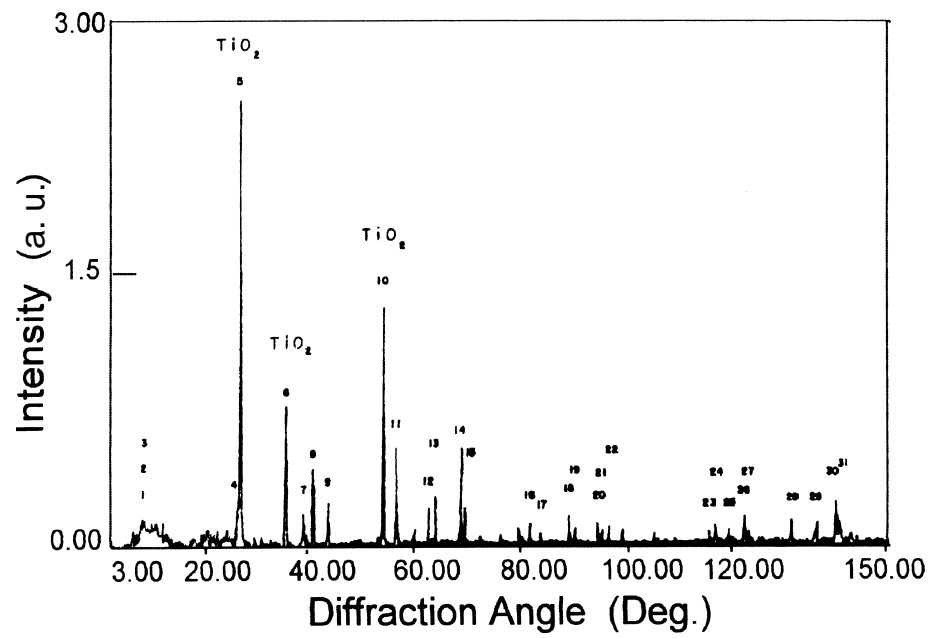

Figure 2: X-ray diffractogram of D50 powder.

diatomite present in the mixture, due to its large porosity.

X-ray diffraction analysis (Figs. 1 and 2) shows that the calcination changed the crystalline structure of titania from anatase to rutile and that the diatomite is amorphous even after thermal treatment.

The differential thermal analysis (DTA ) of diatomite before calcination (Fig. 3) shows a loss of water close to $100^{\circ} \mathrm{C}$ and one endothermic peak due to $\mathrm{OH}$ loss at $335^{\circ} \mathrm{C}$. At $970{ }^{\circ} \mathrm{C}$ a small exothermic peak can be seen due to nucleation of $\mathrm{Al} / \mathrm{Si}$ spinel [4].

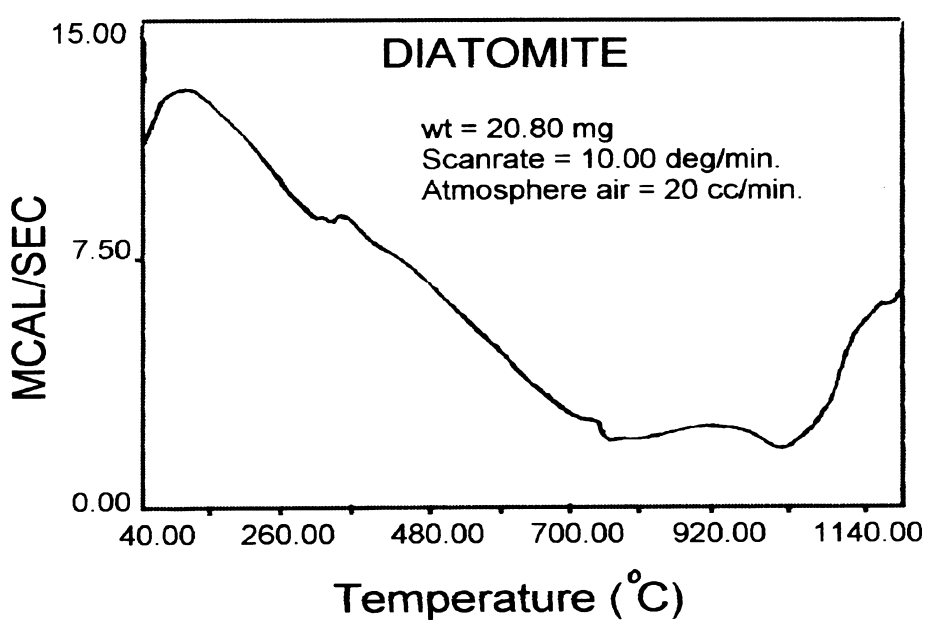

Figure 3: DTA of pure diatomite.

Table I: Chemical analysis of powders; CD: Calcined Diatomite; D: Diatomite; T: Titania.

\begin{tabular}{llll}
\hline Componentes & $\begin{array}{l}\mathbf{C D} \\
{[\mathbf{w t} \%]}\end{array}$ & $\begin{array}{l}\mathbf{D} \\
{[\mathbf{w t} \%]}\end{array}$ & $\begin{array}{l}\mathbf{T} \\
{[\mathbf{w t} \%]}\end{array}$ \\
\hline $\mathrm{TiO}_{2}$ & - & 0.2 & $>99.99$ \\
\hline $\mathrm{SiO}_{2}$ & 95.71 & 88.0 & - \\
\hline $\mathrm{Al}_{2} \mathrm{O}_{3}$ & 3.84 & 4.0 & - \\
\hline $\mathrm{Fe}_{2} \mathrm{O}_{3}$ & 0.21 & 1.5 & - \\
\hline $\mathrm{CaO}$ & 0.19 & 0.5 & - \\
\hline $\mathrm{Na}{ }_{2} \mathrm{O}$ & 0.10 & 3.3 & - \\
\hline $\mathrm{MgO}$ & 0.06 & 0.6 & - \\
\hline $\mathrm{K} 2 \mathrm{O}$ & - & 0.02 & - \\
\hline
\end{tabular}

Another small exothermic peak near $1150{ }^{\circ} \mathrm{C}$ was probably caused by elimination of inorganic material.

Fig. 4 shows results of the thermogravimetric analysis (TGA) of the diatomite calcination. It can be observed about 7\% loss of mass between $100{ }^{\circ} \mathrm{C}$ and $450{ }^{\circ} \mathrm{C}$. The TGA of pure titania (not shown displays a smaller weight loss (about $1.5 \%$ ), evidencing its high purity, confirmed by chemical analysis (Table I).

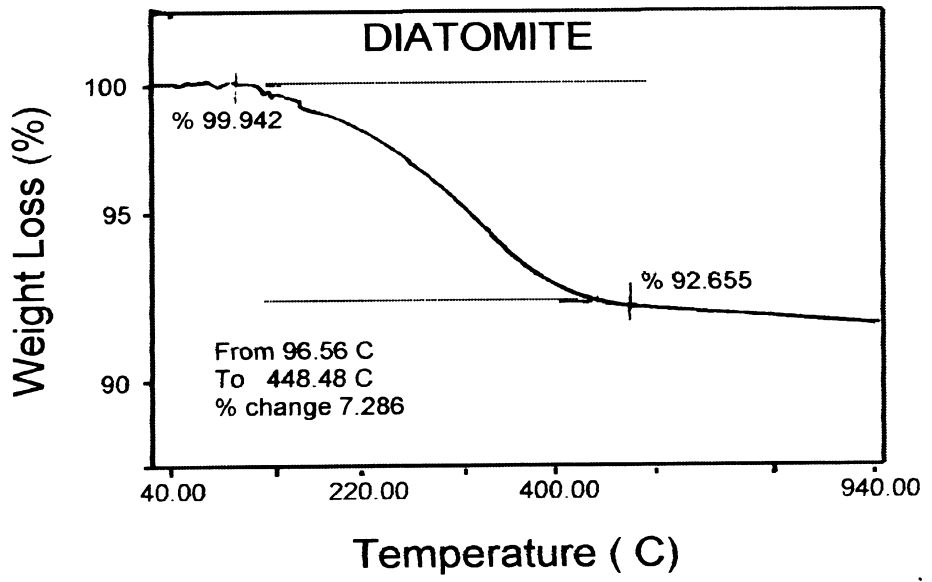

Figure 4: TGA of pure diatomite. 
Fig. 5 shows a typical compressibility slope (charge $\mathrm{x}$ displacing) of the investigated materials.

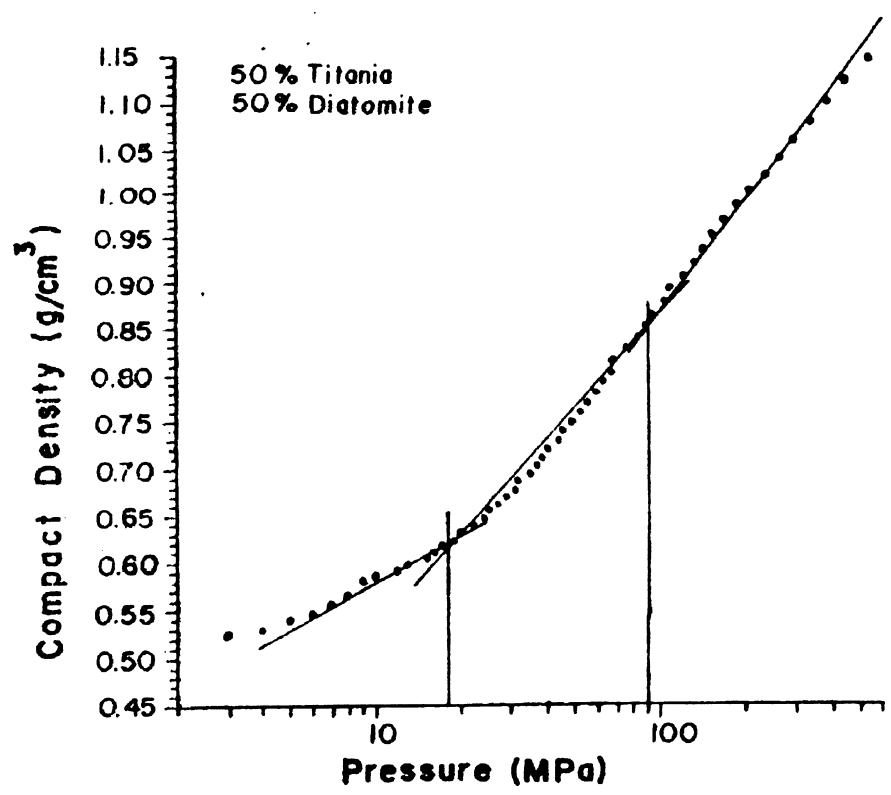

Figure 5: Compressibility slope of D50 powder.

This material shows standard compression behaviour, with samples with 3 distinct pressing regions. The first one remains until the slope changes where break of the cluster occurs. The second one, between the first and the second slope change, due to plastic compression of the particles and the last one, which begins after the second slope change and indicates the break of large particles. The D50 sample slope taken as example shows that the changing points are at $18 \mathrm{MPa}$ and $90 \mathrm{MPa}$. These values increase proportionally to the amount of titania in the sample, due to its greater hardness.

Fig. 6 shows values of the linear shrinkage of the D50 samples as a function of sintering temperature at different times. It can be seen that shrinkage grows proportionally with increasing sintering temperature and time. Other compositions showed similar behaviour, but with the absolute values decreasing with increasing the amount of titania, due to its higher sintering temperature.

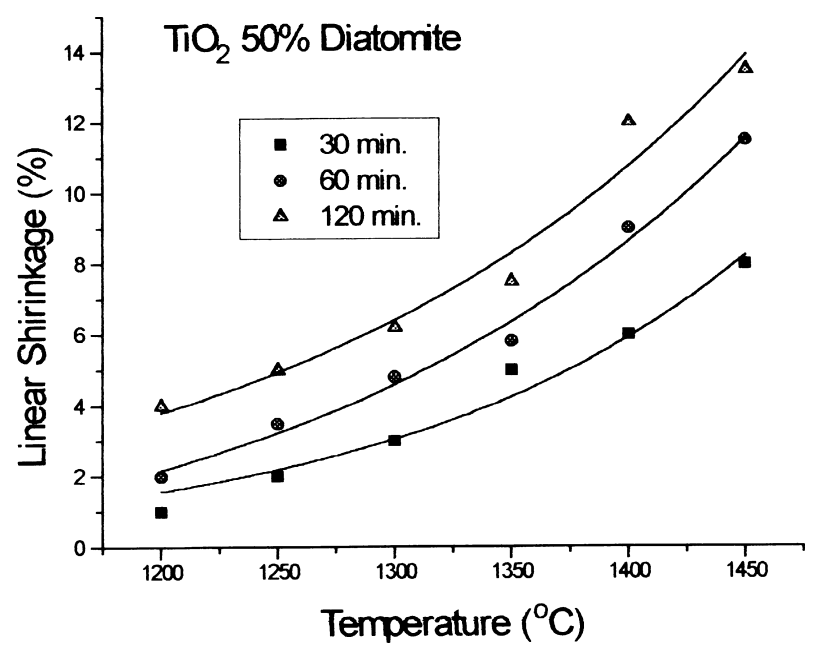

Figure 6: Linear shrinkage of sintered D50 samples as a funtion of sintering temperature at different times.
Table II: Characteristics of the used materials; CD: Calcined Diatomite; CT: Calcined Titania; D75: 75\% Diatomite;D50: 50\% Diatomite; D25: 25\% Diatomite.

\begin{tabular}{lllll}
\hline & $\begin{array}{l}\text { Grain } \\
\text { Size } \\
(\mathbf{M e s h})\end{array}$ & $\begin{array}{l}\text { Apparent } \\
\text { Density } \\
\left(\mathbf{g} / \mathbf{c m}^{\mathbf{3}}\right)\end{array}$ & $\begin{array}{l}\text { Tap Density } \\
\left(\mathbf{g} / \mathbf{c m}^{\mathbf{3}}\right)\end{array}$ & $\begin{array}{l}\text { Specific } \\
\text { Surface } \\
\left(\mathbf{m}^{2} / \mathbf{g}\right)\end{array}$ \\
\hline $\mathbf{C D}$ & 400 & 0.106 & 0.151 & $14-24$ \\
\hline $\mathbf{C T}$ & 400 & 0.679 & 0.909 & 6.7 \\
\hline $\mathbf{D 7 5}$ & 400 & 0.159 & 0.220 & 28 \\
\hline $\mathbf{D 5 0}$ & 400 & 0.240 & 0.360 & 14 \\
\hline $\mathbf{D 2 5}$ & 400 & 0.360 & 0.520 & 9.5 \\
\hline
\end{tabular}

The activation energy, calculated from equation $B$, is shown in Fig. 7. It can be seen that its value increases with the amount of titania, due to its larger sintering temperature.

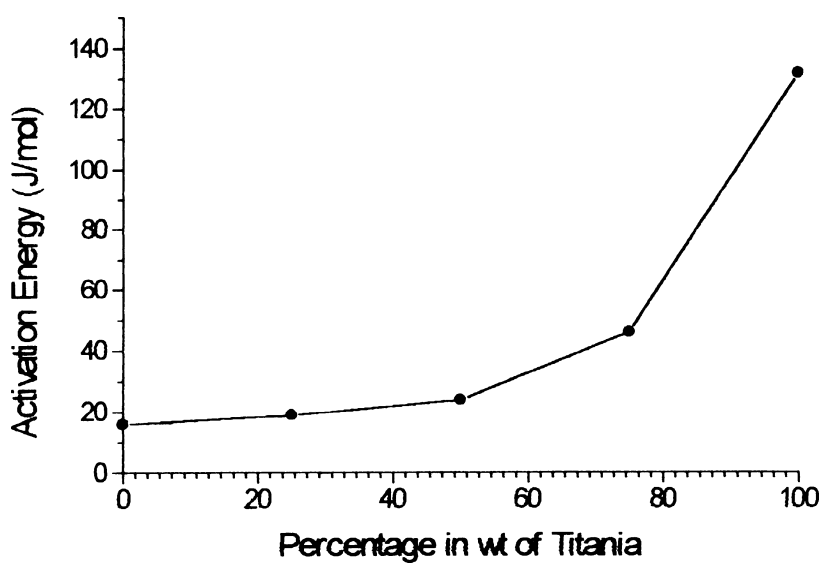

Figure 7: Activation Energy versus titania concentration .

Fig. 8 shows the optical photomicrograph of D50 specimen sintered at $1400^{\circ} \mathrm{C} / 12 \mathrm{~h}$. The microstructure shows titania (bright phase) and diatomite (dark phase), distinctly separated, as already reported $[5,6]$. It can also be seen that diatomite and titania do not form a new phase [7].

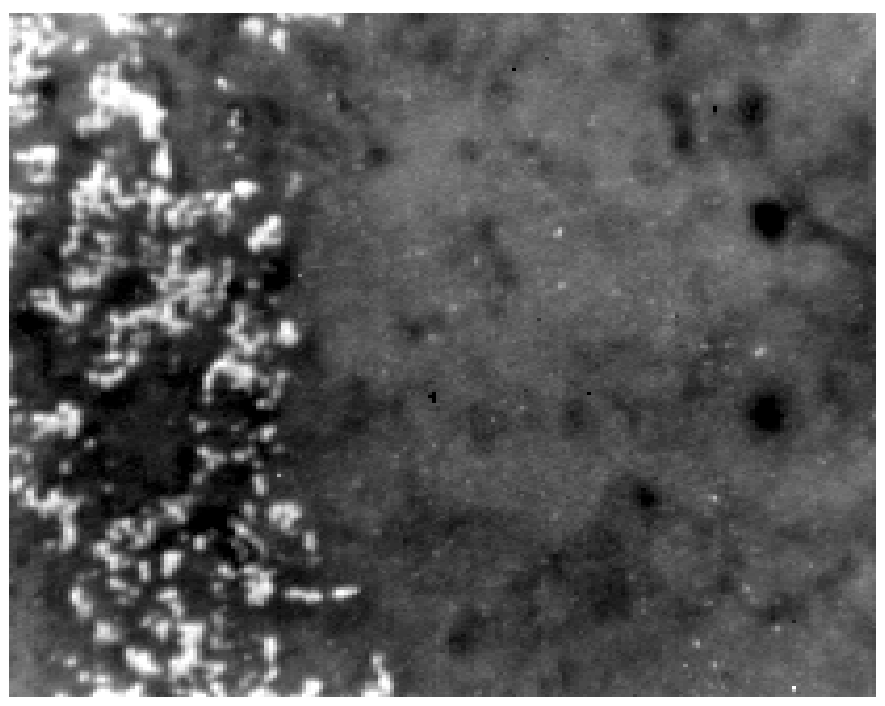

Figure 8: (220 X) Optical photomicrograph of sample D50 sintered at $1400^{\circ} \mathrm{Cl} 12 \mathrm{~h}$. 
Fig. 9 shows the photomicrograph (SEM-3000 X) of the D50 sample sintered at $1250^{\circ} \mathrm{C} / 12 \mathrm{~h}$, with the small grains identified as titania and the great ones as diatomite. It could be seen that diatomite has already a bond among its parts.

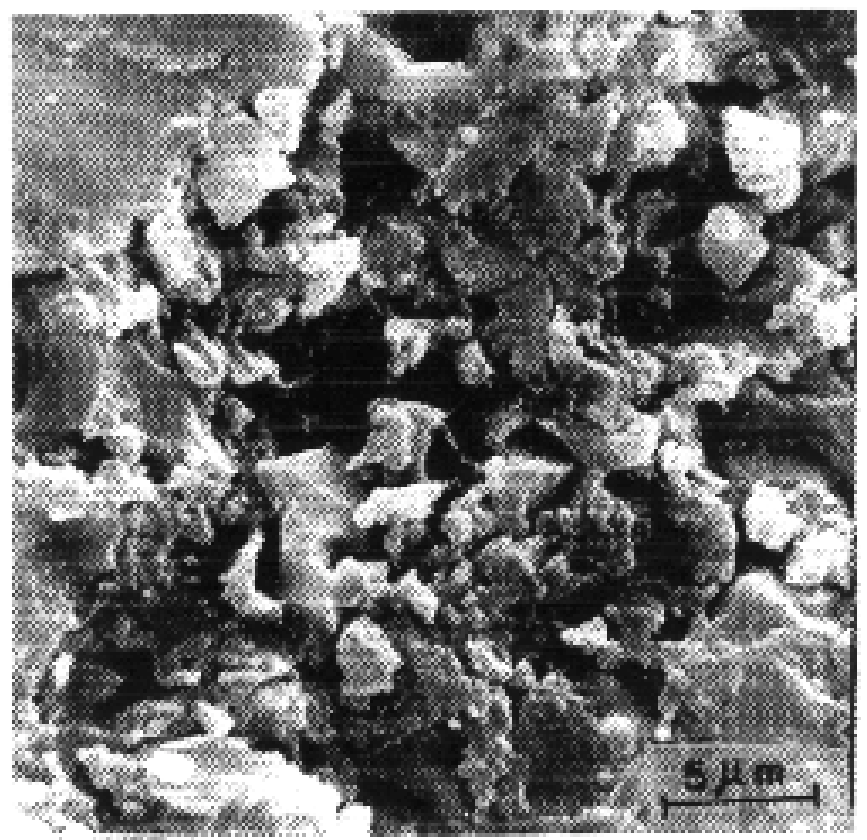

Figure 9: Photomicrograph (SEM-3000 X) of sample D50 sintered at $1250^{\circ} \mathrm{C} / 12 \mathrm{~h}$.

Table III: Theoretical and experimental values of the sintering parameter constant $(K)$, calculated from equation $(B)$.

\begin{tabular}{cl}
\hline MATERIAL & K \\
\hline D100 $\left(1250^{\circ} \mathrm{C}\right)$ & 1.15 \\
\hline $\mathrm{D} 50\left(1250^{\circ} \mathrm{C}\right)$ & 0.66 \\
\hline $\mathrm{D} 100\left(1450^{\circ} \mathrm{C}\right)$ & 0.49 \\
\hline $\mathrm{D} 50\left(1450^{\circ} \mathrm{C}\right)$ & 0.40 \\
\hline
\end{tabular}

The sintering mechanism constant $(\mathrm{K})$ is given in table III. The comparison between measured and theoretical values indicates that the sintering mechanism of the pure diatomite can be described by a viscous flow $(\mathrm{K}=1)$, in agreement with Gramatikov et al [8] . The increase in titania content decreases the value of the parameter constant $(\mathrm{K})$, because the plastic flow (sintering mechanism of the pure titania) starts to compete with the viscous one.

\section{CONCLUSIONS}

Even though the impurity content of diatomite varies depending on the extraction site, it was found that a $200 \mathrm{MPa}$ pressure is suitable for attaining a good hardness of the green body. The sintering of diatomite occurs by viscous flow up to $1200{ }^{\circ} \mathrm{C}$ for $12 \mathrm{~h}$, changing after this point to liquid phase. The sintering process of titania can be described as plastic flow, and the mixtures show a competition in sintering mechanism between plastic flow and liquid phase. The optimum sintering condition is $1300{ }^{\circ} \mathrm{C} / 2 \mathrm{~h}$, because it gives the largest shrinkage with minimum energy.

\section{REFERENCES}

[1] J.E. Burke, in "Ceramic Fabrication Processes", edited by W.D. Kingery, MIT Press, Massachusetts, pp. 120-131(1958).

[2] O. J. Whittemore Jr., J. H. C. Castro, "Physical characteristics of Brazilian Diatomites", Proc. Mat. Equipments Div. $78^{\text {th }}$ Annual Meeting of the American Ceramic Society, 48 (1976).

[3] M. A. F. Melo "Diatomite", Apostile of the discipline Clay Technology of the Federal University of Rio Grande do Norte, (1992) (In Portuguese).

[4] S. L. Moro, P. K. Kyoara, P. S. Santos, "Preliminary Study of Brazilian diatomites in laboratory scale”, Ceramica, 27, 144 (1991).

(In Portuguese).

[5] T. Kokubu and M. Yamane "Preparation of Porous GlassCeramics of the $\mathrm{TiO}_{2}-\mathrm{SiO}_{2}$ System”, J.Mat. Sci. 20 (1985) 4309.

[6] P. Taylor, "Peculiar Morphology in Some Phase-separated Multicomponent Silicate Glasses”, J. Am. Ceram. Soc. 75, 5 (1992) 1276.

[7] E. C. S. Tavares, J. P. Medeiros, U. U. Gomes, "Microstructural Analysis of Diatomite - Titania ceramic powders mixtures Proc. $37^{\text {th }}$ Brazilian Congress on Ceramics (1994).

[8] D. D. Gramatikov, M. I Milosevski and M. M. Ristic, Proceedings of the $5^{\text {th }}$ Intern. Round Table Conference on Sintering, Portoroz, Yugoslavia, September 1981, ed.: D. Kolar, S. Pejovnik and M. M. Ristic (1981).

(Rec 96, Rev. 26/05/97, Ac. 03/98) 